\title{
Physical, physiological and anatomical changes in Erythrina speciosa Andrews seeds from different seasons related to the dormancy degree ${ }^{1}$
}

\author{
Debora Manzano Molizane ${ }^{2}$, Pricila Greyse dos Santos Julio ${ }^{3}$, \\ Sandra Maria Carmello-Guerreiro ${ }^{4}$, Claudio José Barbedo ${ }^{2 *}$
}

\begin{abstract}
Dormancy, a process that allows seeds to survive in adverse environments, needs to be broken for germination to start, for example, by the disruption of the impermeable layer of seeds. Mature seeds of Erythrina speciosa present seed coat impermeability, whose degree depends on the year of production. The objective of this study was to analyze the physical, physiological, anatomical, and ultrastructural seed coat modifications, according to the environmental conditions in which seeds were produced, as well as the seed sensitivity to treatments as for breaking dormancy. E. speciosa seeds were collected for six years in a row and were analyzed as for dormancy degree. Moreover, chemical scarifications by different immersion times were applied on seeds from two production years, as well as mechanical scarification, which was an efficient methodology to overcome dormancy. Different immersion times by acid scarification were necessary to break dormancy in each harvest year. It was possible to conclude that the climatic conditions under which the mother plant is submitted can influence the dormancy degree of E. speciosa seeds, but the expected anatomical changes between dormant and non-dormant seeds were not found in seeds from this species.
\end{abstract}

Index terms: Leguminosae, sead coat impermeability, tropical tree species.

\section{Alterações físicas, fisiológicas e anatômicas em sementes de Erythrina speciosa Andrews de diferentes épocas, relacionadas com o grau de dormência}

\begin{abstract}
RESUMO - A dormência, um processo que permite que as sementes sobrevivam em ambientes adversos, precisa ser quebrada para iniciar a germinação, por exemplo, pela ruptura da camada impermeável de sementes. Sementes maduras de Erythrina speciosa apresentam impermeabilidade do tegumento da semente, cujo grau depende do ano de produção. O objetivo deste estudo foi analisar as modificações físicas, anatômicas e ultraestruturais da casca da semente, de acordo com as condições ambientais em que as sementes foram produzidas, bem como a sensibilidade das sementes a tratamentos para quebra de dormência. Sementes de E. speciosa foram coletadas durante seis anos consecutivos e analisadas quanto ao grau de dormência. Além disso, escarificações químicas por diferentes tempos de imersão foram aplicadas em sementes de dois anos de produção, bem como escarificação mecânica, que foi uma metodologia eficiente para superar a dormência. Diferentes tempos de imersão por escarificação ácida foram necessários para quebrar a dormência em cada ano de colheita. Concluiu-se que as condições climáticas nas quais a planta-mãe é submetida podem influenciar no grau de dormência de sementes de $E$. speciosa, mas não foram encontradas alterações anatômicas usualmente esperadas entre sementes dormentes e não-dormentes dessa espécie.
\end{abstract}

Termos para indexação: Leguminosae, impermeabilidade do tegumento, espécie arbórea tropical.

\section{Introduction}

The seed coat is an essential structure, both physically and

${ }^{1}$ Submitted on 05/16/2018. Accepted for publication on 06/06/2018. ${ }^{2}$ Instituto de Botânica, Núcleo de Pesquisa em Sementes, 04301-902 - São Paulo, SP, Brasil.

${ }^{3}$ Universidade Estadual de Mato Grosso do Sul, Cidade Universitária de Dourados, 79804-970 - Dourados, MS, Brasil. physiologically. As well as being a protective barrier between the embryo and the environment, the structural and molecular variations found among different coats deeply influence the

${ }^{4}$ Instituto de Biologia, Universidade Estadual de Campinas, 13083-862 Campinas, SP, Brasil.

*Corresponding author <cjbarbedo@yahoo.com.br> 
physiology of the seed. Particularly, the variations found in the coat thickness affect germination and dormancy (Coen and Magnani, 2018).

Seed coat impermeability to water or gas is known as physical exogenous dormancy and is a common phenomenon among Fabaceae species. This type of dormancy can be caused by several factors, which can be isolated or combined. Among several causes, it is possible to mention the presence of cuticles and waxes and the oxidation of phenolic compounds found in the pigmented cells of the coat (MarcosFilho, 2015). In order to initiate the germination process, it is necessary to have a rupture in this impermeable layer; this can be done artificially by mechanical scarification or with corrosive chemical substances, such as acids. For example, the application of sulfuric acid for five minutes breaks the dormancy of Stylosanthes humilis seeds (Chaves et al., 2017).

The environmental conditions to which the mother plant is submitted can interfere with the seed maturation process, causing changes in their physiological quality and also to the establishment of physical dormancy (Hay et al., 2010; Gama-Arachchige et al., 2011). Apparently, both the zygote environment and the environment of the mother plant can act on the establishment of dormancy, which may also cause changes in fruit and seed tissues (Penfield and MacGregor, 2017). The insolation degree, for example, may interfere with dormancy intensity: environments with higher insolation double the probability of producing dormant seeds (Souza et al., 2015). Another important factor is temperature. Generally, seeds formed under lower temperatures present a higher dormancy degree, especially among annual species (Huang et al., 2017; Penfield and MacGregor, 2017). However, these relations are have not been fully proven yet, just like the relation with other environmental factors, both regarding the degree of dormancy established in seeds and their susceptibility to processes of dormancy breaking. These were the objectives of this work, with seeds of Erythrina speciosa (Leguminosae, Faboideae), which were physically, physiologically, anatomically, and ultrastructurally analyzed. E. speciosa is distributed throughout the Cerrado and Atlantic Forest regions; it has an arboreal aspect, between 3 and 5 meters in height, and is widely used as an ornamental plant. Its seeds are tolerant to desiccation and have an impermeable coat to water absorption (Pilatti et al., 2010; Mello et al., 2010).

\section{Material and Methods}

Fruits of Erythrina speciosa were collected from 30 plants in the Parque Cultural Catavento, in an urban area of São Paulo city, in October 2010, 2011, 2012, 2013, 2014, and 2015. They were immediately taken to the Seed Laboratory of the Botany Institute (Laboratorio de Sementes do Instituto de Botânica), where seeds were extracted manually. After that, seeds were analyzed as for their moisture content and dry matter content by oven method at $103{ }^{\circ} \mathrm{C}$ for 17 hours (Brasil, 2009). The results were presented, respectively, as percentage (wet basis) and $\mathrm{mg}^{-s} \mathrm{ee}^{-1}$.

Germination tests were then conducted as follows: without scarification treatments (SE) for seeds collected in 2012; with previous mechanical scarification (MS), as well as SE, for the 2013, 2014, and 2015 collections; SE, MS and scarification in sulfuric acid $\left(\mathrm{H}_{2} \mathrm{SO}_{4}, \mathrm{PA}\right.$, hereafter referred to as acid scarification), with $0.5,1,3,5,10,15,40$, and 60 minutes immersions for the 2010 and 2011 collections. Germination tests were installed on paper rolls that had been previously moistened with water by 2.5 times the paper weight (Brasil, 2009) and incubated in a germination room regulated at $25{ }^{\circ} \mathrm{C}$ with a relative humidity of $70 \%$. Evaluations were carried out every other day for 30 days, and seeds that emitted a primary root with an equal to or greater than $0.5 \mathrm{~cm}$ size were recorded for the calculation of germination percentage and mean germination time (Santana and Ranal, 2004).

In order to estimate intensity and imbibition rate, a hydration curve was carried out with 20 seeds without scarification, and also with a 15 and 40 minutes acid scarification, for the 2010 and 2011 collections. Seeds were placed to soak at $25{ }^{\circ} \mathrm{C}$ on a double sheet of germination paper, as described above. Each seed was weighed initially and after 24, 48, and 72 hours.

The opposite region to the hilum of intact seeds from all collections (2010 to 2015) and also from all acid scarification treatments from the 2010 and 2011 collections was analyzed anatomically. For this, seed samples were fixed in FAA70 and stored in $70 \%$ ethanol, infiltrated in plastic resin, transversely sectioned with a disposable razor in an RM 2245 manual rotary microtome, at a $7 \mu \mathrm{m}$ thickness, and stained with $0.05 \%$ toluidine blue (O'Brien et al., 1964). The analysis of the slides was performed in an Olympus BX51 photomicroscope and scaled images were obtained by an Olympus DP71 coupled camera in the DPManager software. From these images, differences presented by the coat of intact seeds from the six collections were analyzed with the help of the ImageJ software, and the following structures were measured: length, wall and cuticle thickness of palisade exotesta cells and height of hourglass cells and their underlying parenchyma.

Ultrastructural analyses were also carried out after the acid scarification of the 2010 and 2011 collections. Seeds were placed in metal capsules and then placed to dry in a forced air circulation oven at $50{ }^{\circ} \mathrm{C}$ for three days. Seeds with no treatment to overcome dormancy were also analyzed. For 
the scanning electron microscope (SEM) analysis, seed testa were cut with a scalpel blade and then adhered to the stub with a conductive adhesive tape. The samples were plated with ionized gold in argon atmosphere by a SCD 050 Bal-tec metallizer, with a deposition time of $80 \mathrm{~s}$ and a current of 40 $\mathrm{mA}$. After metallization, samples were scanned into a XL20 electron microscope for observation.

Climatic data (maximum and minimum temperature and precipitation) from the six studied years were obtained from the meteorological stations installed in the USP Parque de Ciência e Tecnologia (Science and Technology Park

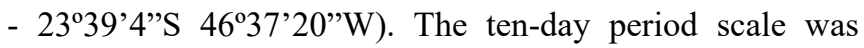
calculated through the mean at every ten days of the studied years, for maximum and minimum temperature, and the sum at every ten days for precipitation. The sequential water balance was also calculated with precipitation data, using the model proposed by Thornthwaite and Mather, in decreasing order of a $125 \mathrm{~mm}$ water available capacity scale level (Leivas et al., 2006; Rolim et al., 2007).

The experimental design was completely randomized. Each treatment had four replications with 20 seeds for the physiological analyses, and four replications of five seeds for the physical analyses. Data were submitted to analysis of variance (F test) and the means were compared by Tukey's test, at a 5\% level, using the R statistical program. A correlation analysis of the climatic data from the six collection years was also carried out, with physical, physiological, and anatomical data.

\section{Results and Discussion}

The moisture content and dry matter content of Erythrina speciosa seeds did not vary a lot between the collections from the different years ( $9 \%$ to $12 \%$ moisture, 0.31 to 0.35 gDM.seed $^{-1}$, Figures $1 \mathrm{a}$ and $\mathrm{b}$ ), indicating that they were collected when mature (Mello et al., 2010, 2011). Germination results from the different samples showed the variation in dormancy intensity, which was lower in the 2010 and 2014 collections (more than $40 \%$ of seeds germinating without scarification) and higher in the 2011, 2012 and 2015 ones (less than 5\%). This variation throughout the different collections is expected, as already demonstrated for other species, depending on the environmental conditions under which seeds develop (Souza et al., 2015; Huang et al., 2017; Penfield and MacGregor, 2017). The mean germination time (MGT) presented differences according to the collection year (Figure 1d), being higher in 2010, 2011 and 2012, and lower in 2013, 2014 and 2015. When mechanically scarified, almost all seeds germinated (Figure 1e), and this germination ocurred in a very short period (Figure 1f).
The results obtained with the germination of seeds scarified with sulfuric acid demonstrated the variation in sensitivity to dormancy overcoming between seeds from the 2010 and 2011 collections (Figure 1g). In order to reach $50 \%$ germination in the 2011 lot, 15 minutes of exposure to the acid were required, whereas the same value was exceeded in only $1 \mathrm{~min}$ in seeds from 2010. To reach values close to $100 \%$, only 15 min were necessary for the 2010 collection; on the other hand, in the 2011 collection, it took 40 minutes. Differences were also observed within the same collection, by the imbibition curve (Figure 2). Seeds from the 2010 collection, in the treatment with acid immersion for 15 and 40 minutes (Figures 2b, c), presented more soaking seeds compared to the same treatment in the 2011 collection (Figures 2e, f). It was also possible to observe a variation between the 2010 seeds exposed to 15 minutes of acid; some overcame dormancy in 24 to 48 minutes, and others needed $72 \mathrm{~min}$, besides those that did not fully soak in the first 72 minutes (Figure $2 b$ ).

E. speciosa seeds have a dark brown coat. The testa consists in an outer layer in high palisade, the exotesta, with a cellular content that is rich in phenolic compounds and with a light line close to the external periclinal wall; the same was observed for E. lysistemon Hutch seeds (Manning and Staden, 1985). Anatomical differences could not be observed on intact seeds from all collections (Figure 3). The measurements performed on the structures did not present statistical differences that indicated a correlation with the germination percentages of intact seeds. The cuticle that covers the palisade cells (exotesta) of seeds from the 2010 collection (Figure 3a) is thinner than the seeds from the other collections; this may facilitate the entry of water. However, this reduction in cuticle thickness was not observed in the 2014 collection (Figure 3e). These results are different from those obtained by Chai et al. (2016), who suggested that palisade cell size and cuticle thickness may be responsible for dormancy, due to water impermeability. Dormant seeds had a dense light line, a thicker cuticle and larger palisade cells than non-dormant seeds.

In the acid scarification treatments, it was possible to observe anatomical differences (Figure 4). In the sulfuric acid immersion periods, 0.5 min (collection 2010, Figures 4b; 5b) and $1 \mathrm{~min}$ (collection 2011, Figures 41; 5o) presented only cuticle corrosion. The cuticle was removed with $1 \mathrm{~min}$ immersion for 2010 collection (Figures 4c; 5c), and after 10-15 min for 2011 collection (Figures 4o; 5s), which suggests that 2011 collection had seeds with higher degree of dormancy. From 40 to 60 minutes of immersion, it is possible to observe a slightly deep corrosion of palisade cells (Figures 4h, i, q, r; Figures 5s, t). 

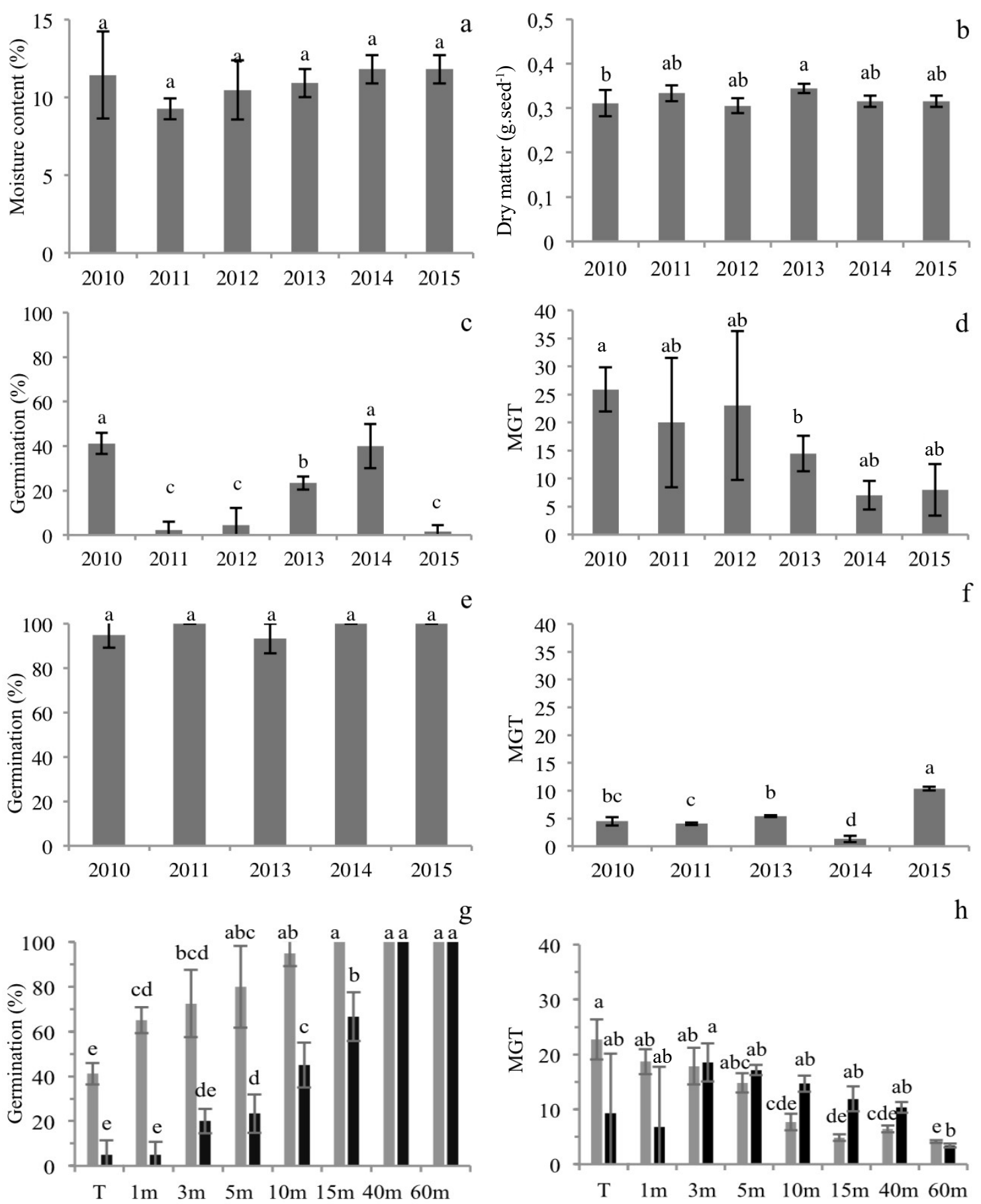

Figure 1. Physical and physiological responses of mature Erythrina speciosa seeds (a) Moisture content. (b) Dry matter. (c) Seed germination without any treatment to overcome dormancy (Test.). (d) Mean germination time (MGT) of the seed without any treatment (e) Germination of seeds with mechanical scarification (f) MGT of seeds with mechanical scarification. (g) Germination of seeds with acid scarification for different periods (gray columns: 2010; black: 2011). (h) MGT of seeds with acid scarification for different periods (gray columns: 2010; black: 2011). Same letter indicates no statistical difference between two treatments. $\mathrm{T}=$ no treatment to overcome dormancy. $\mathrm{m}=$ Minutes. 


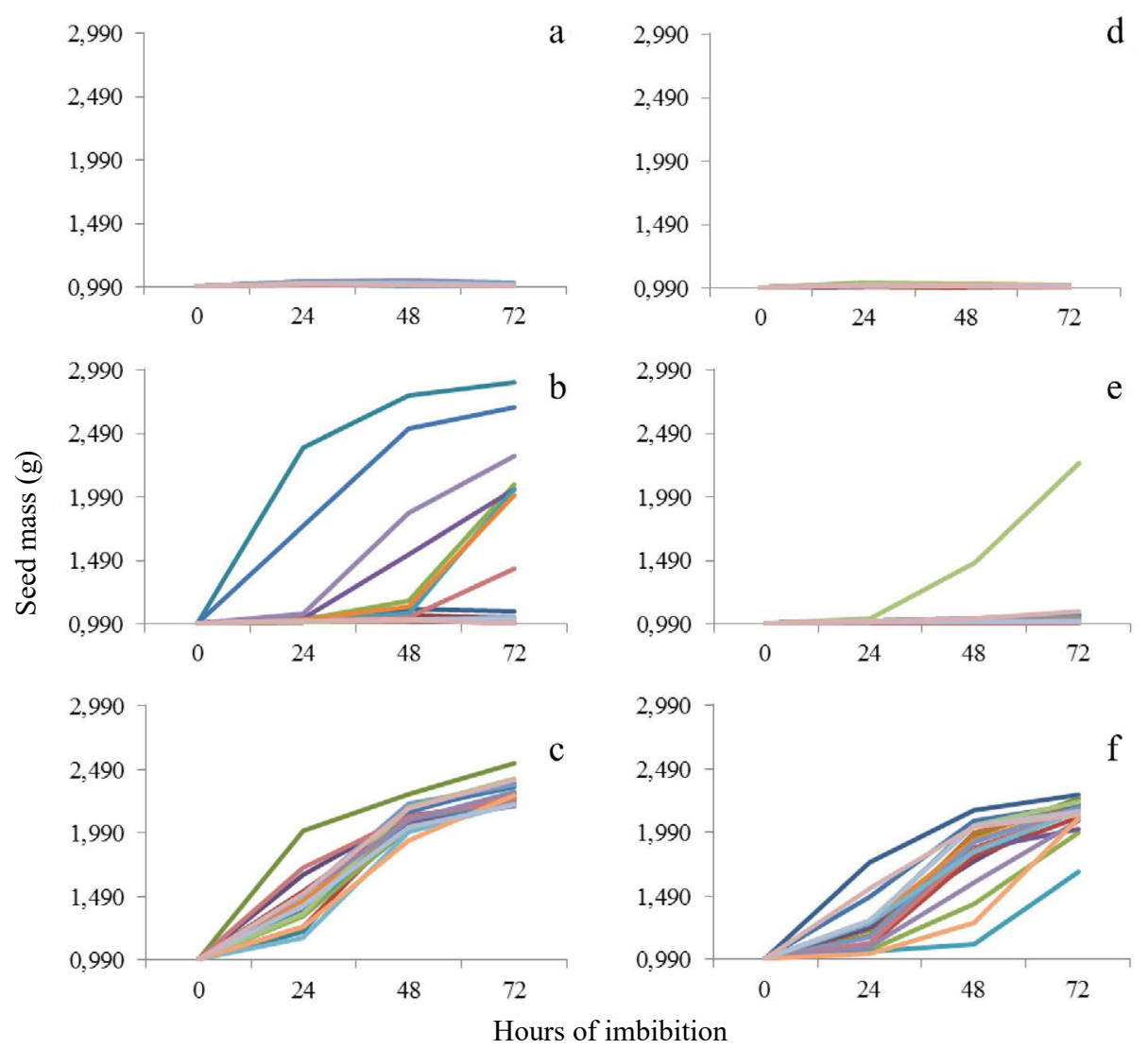

Figure 2. Weight gain in Erythrina speciosa Andrews seeds during imbibition in the two collected years, 2010 (a, b, c) and 2011 (d, e, f). (a and d) control treatment; ( $b$ and e) immersion in concentrated sulfuric acid for 15 minutes; (c e f) immersion in concentrated sulfuric acid for 40 minutes. Each line indicates one seed.
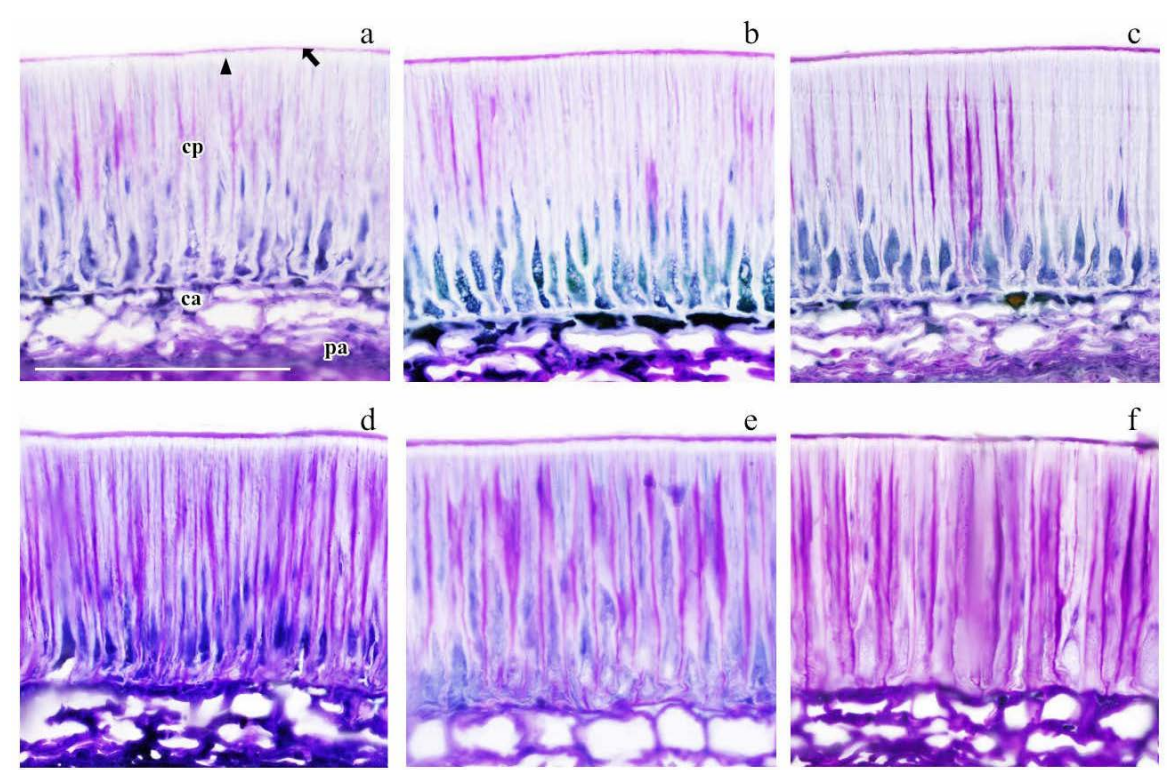

Figure 3. Anatomy of the testa of mature E. speciosa seeds (stage 6), analyzed in six consecutive years. (a) 2010; (b) 2011; (c) 2012; (d) 2013; (e) 2014; (f) 2015. Scale $100 \mu \mathrm{m}$ ca - hourglass cells; cp - cells in palisades; pa - parenchyma; arrow tip - cuticle; tip of the triangle - light line. 

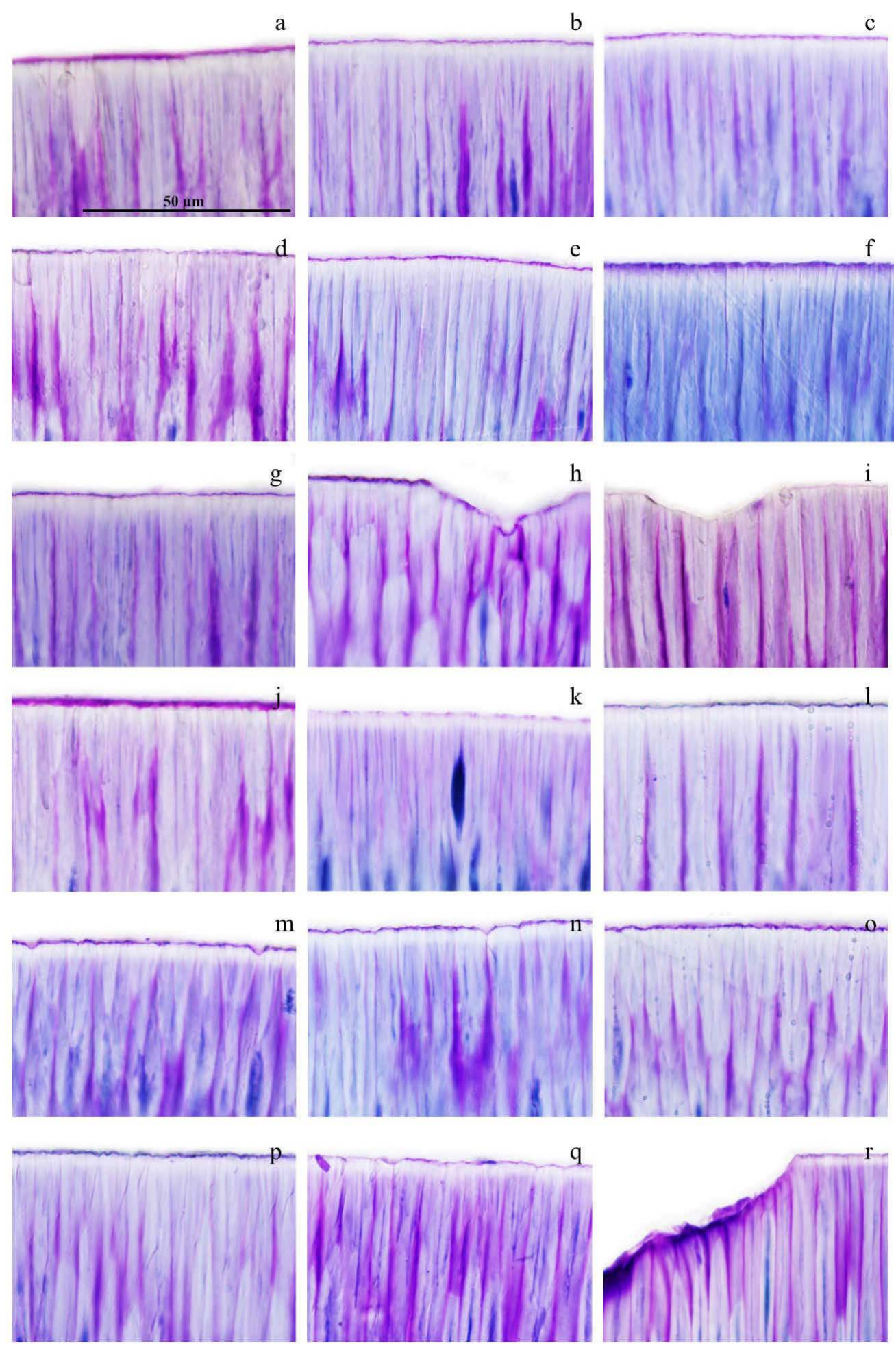

Figure 4. Anatomy of the testa of mature E. speciosa seeds (stage 6), analyzed, collected, and submitted to acid scarification (a-i) 2010 collection; (j-r) 2011 collection. Scale $50 \mu \mathrm{m}$. Coat detail: (a, j) control treatment, (b, k) 0.5 minute, (c, l) 1 minute, (d, m) 3 minutes, (e, n) 5 minutes, (f,o) 10 minutes, (g, p) 15 minutes, (h, q) 40 minutes, (i, r) 60 minutes. 
The cuticle was removed with 1-0 minute immersion for 2010 collection (Figures 4c, 5c), and after 10-15 minutes for 2011 collection (Figures 4o, 5s), which suggests that 2011 collection had seeds with higher degree of dormancy. From 40 and 60 minutes of immersion, it is possible to observe a slightly deeper corrosion of palisade cells (Figures 4h, i, q, r; 5s, t).

In the 2010 collection, it was observed that acid penetration occurred in points with lower resistance, between the middle lamellae (Figures 5j, k, 1); in 2011 (Figures 5v, $\mathrm{w}, \mathrm{x})$, corrosion occurred in more extensive areas, but at a lower depth, thus corroborating the dormancy difference between the two collection years. In the ultrastructural analyses, it was possible to observe differences in the sulfuric acid immersion treatments, corroborating the observed anatomical results. After the cuticle corrosion, in the 2010 collection, it was possible to observe that corrosions are larger in extent and less deep. On the other hand, in the 2011 collection, coat corrosions were larger and deeper until the 40th minute of immersion. It is possible to observe that the complete removal of the cuticle in the 2010 collection took place within 1 minute of immersion in the acid, where the germination percentage reached $24 \%$ more than the control treatment. In the 2011 collection, the total removal of the cuticle occurred in 10 minutes, exceeding by $35 \%$ more in germination if related to the control treatment.

It is possible that the difference in the sulfuric acid corrosion areas presented in the two collections promotes a greater or lower penetration of water into internal regions of seeds. Therefore, it can be assumed that compounds promoting physical dormancy are not equally deposited across the testa of the seeds. Palisade cell walls are composed of cellulose and pectic compounds, marked by the magenta color of the walls given by toluidine blue, without wall lignification. Pectins are partially esterified glycosidic macromolecules; they are abundant in the middle lamella, forming an adhesive between the primary walls of plant cells. Pectin, in general, remains stable at $\mathrm{pH}$ 3. This condition can be altered according to a $\mathrm{pH}$ reduction, to the presence of $\mathrm{Ca}^{2+}$ ions and to the sugar content of seeds. When pectin is in a strong acid medium, hydrolysis occurs and there is the formation of a thermo-reversible gel (Uenojo and Pastore, 2007; Belitz et al., 2009).

In the correlation analysis, no significance was observed between the water stress due to the lack of water in the soil and the degree of physical dormancy presented by $E$. speciosa. Therefore, regardless of the water balance found in the soil (Figure 6), the germination obtained in these collections did not follow a pattern, as observed in the 2011 and 2014 collections.

A positive correlation was observed between moisture content and germination: the higher the moisture content, the higher the germination percentage without any scarification treatment (Table 1). Results that correlated moisture content and germination were observed in Geranium carolinianum L. seeds, in which seeds that had been dried up to $11 \%$ of water presented dormancy, whereas seeds with $13 \%$ did not present dormancy (Gama-Arachchige et al., 2011). In E. speciosa seeds, the correlation analysis showed a significant response, so the higher the moisture content, the higher the germination percentage.

Observing correlation results, May was an important month for the dormancy of mature seeds of E. speciosa, despite the fact that flowers were in development that month and that they were in anthesis between June and August. It was possible to observe a negative correlation between relative humidity and moisture content in May. There was also a negative correlation between germination percentage and relative humidity in May. There may be chemical signals during the period of floral formation that may affect dormancy in the seeds that will develop. In September, a negative correlation was observed between relative humidity and dry matter. As seeds are already developing in this period, with water being replaced by dry matter, relative humidity may be important for the deposition of dry matter in the seed cells. Changes in relative humidity (Figure 6) may affect sap translocation in the plant. As relative humidity increases, the water column movement and evaporation decrease, affecting the translocation of the photosynthesized compounds. Regardless of the water balance found in the soil (Figure 6), the germination obtained in these samples did not follow a pattern. As an example, in the 2011 and 2014 collections, when water deficit occurred during maturation, there was also a significant difference between the germination percentages, $2 \%$ and $40 \%$, respectively.

Finally, the results obtained in this work allowed verifying that different conditions during the formation of Erythrina speciosa seeds cause differences in both their dormancy degree and their sensitivity to breaking by acid scarification. However, anatomically, seeds have the same head structures and, consequently, associating coat impermeability to water and structural changes, alone, seem to find no support in the results. The structural change often associated with the coat impermeability to the shell, that is, the loss of the lumen of palisade cells by the thickening of the epidermal cells (Smýkal et al., 2014), occurred in both dormant and nondormant seeds. Therefore, it is likely that the imposition of dormancy is not necessarily related to these structures, and some biochemical change may be necessary. It is more likely for this impermeability to be due to structural and biochemical 

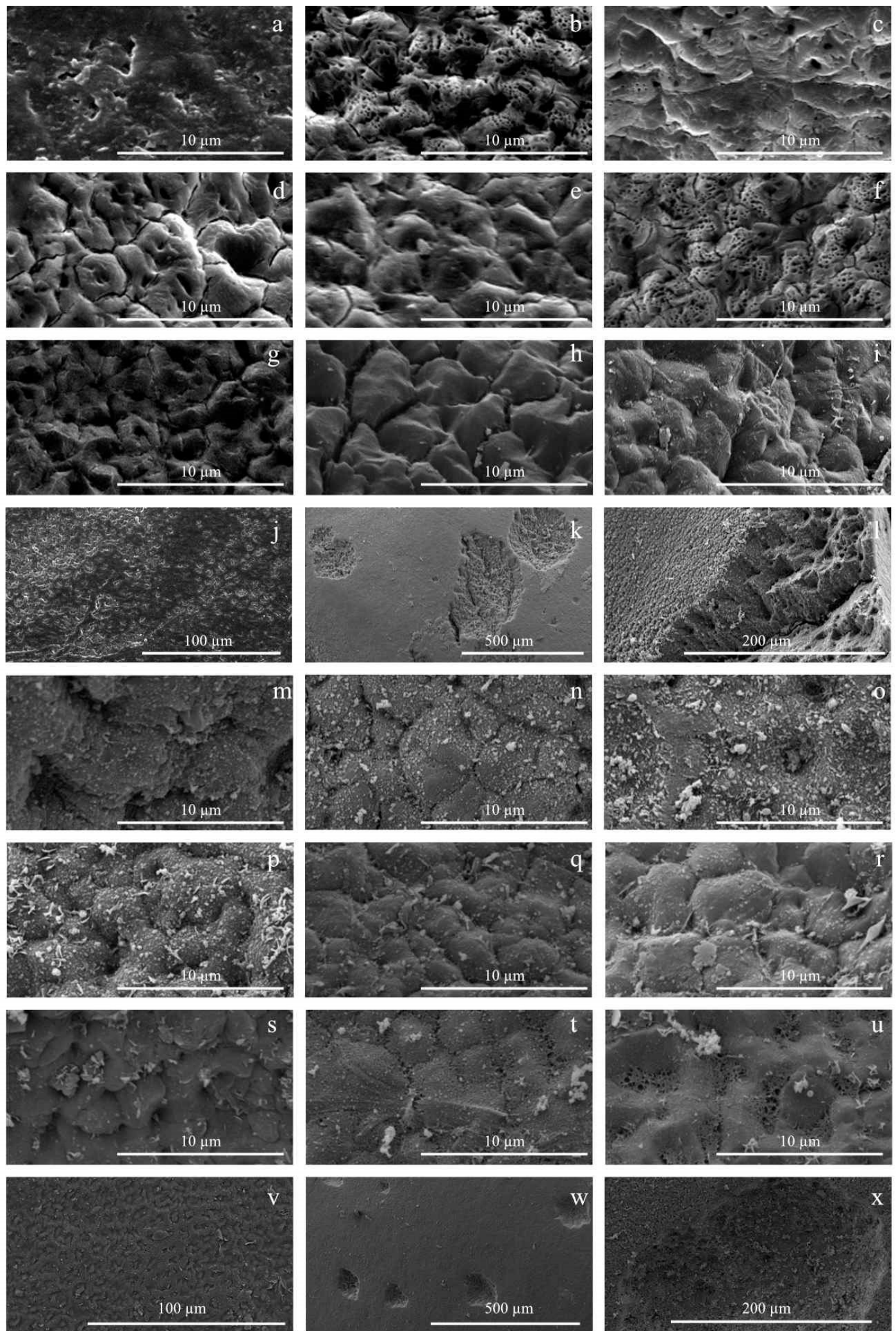

Figure 5. Micrographs obtained with a Scanning Electron Microscope (SEM) from the coat of Erythrina speciosa Andrews seeds, collected in 2010 (a-l) and 2011 (m-x), in sulfuric acid immersion treatments. Coat detail: (a, m) Control treatment, (b, n) 30 seconds, (c, o) 1 minute, (d, p) 3 minutes, (e, q) 5 minutes, (f, r) 10 minutes, (g, s) 15 minutes, (h, t) 40 minutes, (i, u) 60 minutes. Overview: (j, v) control, (k, w) 40 minutes, $(1, x) 60$ minutes. 

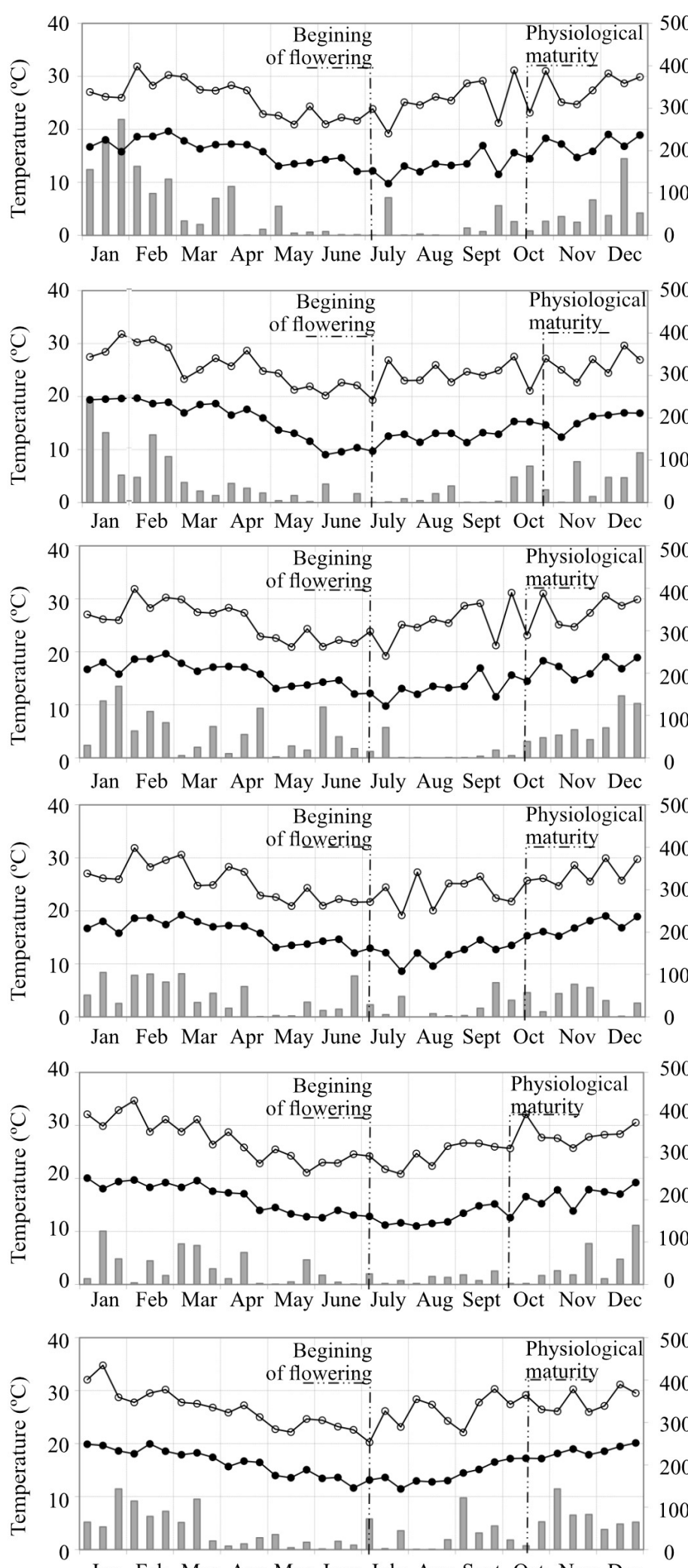

0

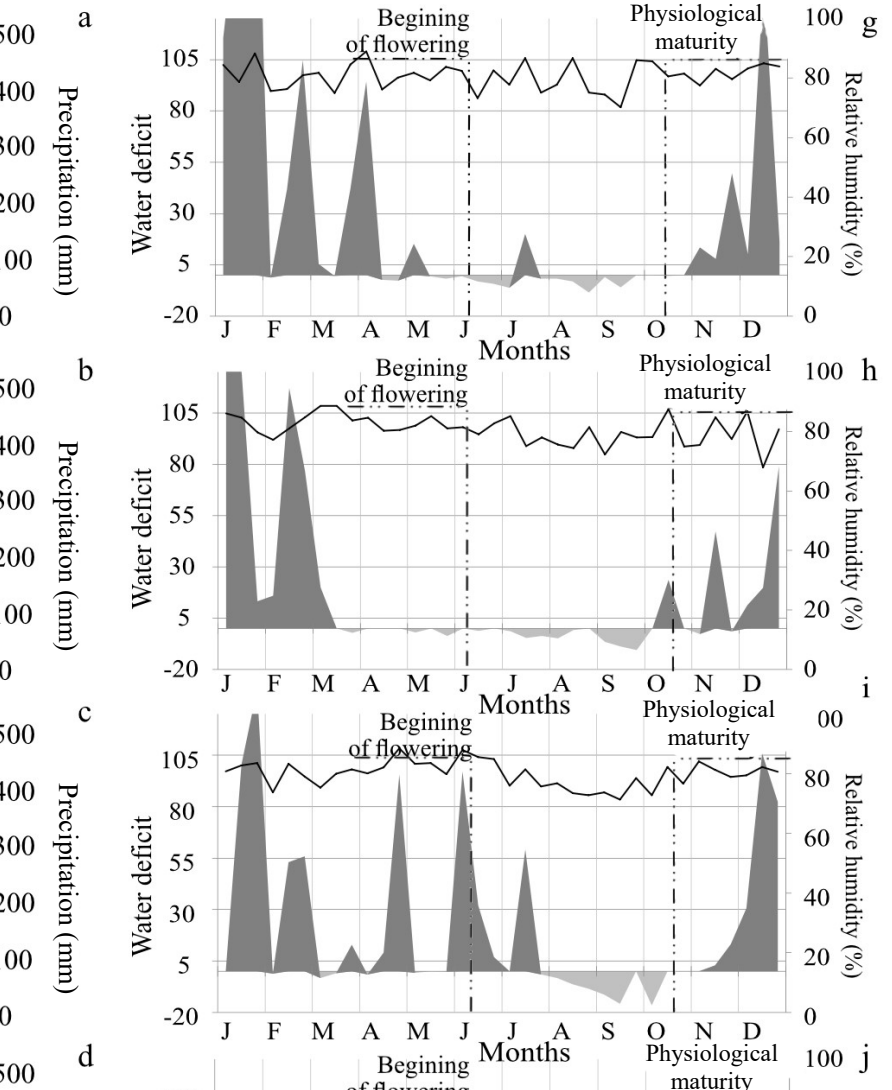

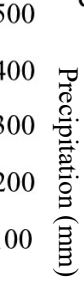

$500 \mathrm{e}$

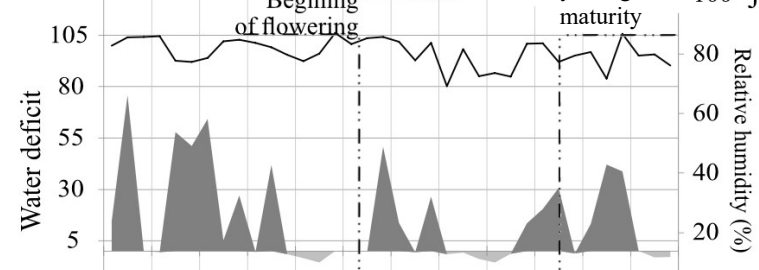

$\begin{array}{lllllllllllllllll}-20 & & \text { J } & \text { F } & \text { M } & \text { A } & \text { M } & \text { J } & \text { J } & \text { A } & \text { S } & \text { O } & \text { N } & \text { D } & 0\end{array}$

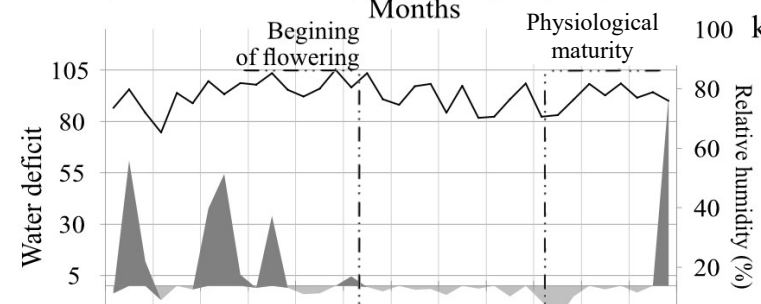

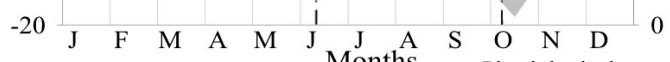

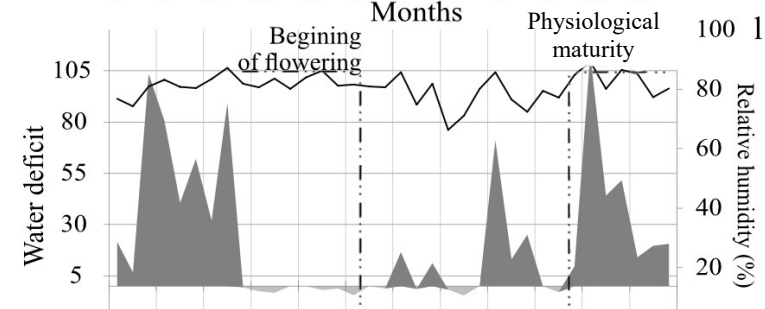

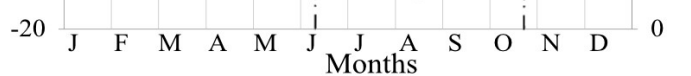

Figure 6. Climatic conditions and water deficit during the 6-year maturation evaluation of Erythrina speciosa seeds. Precipitation, ten-day period minimum and maximum temperatures (a-f). Water deficit and ten-day period relative humidity (g-1). 2010 (a, g). 2011 (b, h). 2012 (c, i). 2013 (d, j). 2014 (e, k). 2015 (f, l). 
Table 1. Correlation of the physiological and climatic data occurred during the 6 years of maturation evaluated in Erythrina speciosa seeds.

\begin{tabular}{cccc}
\hline & Germination & $\begin{array}{c}\text { Relative } \\
\text { humidity in } \\
\text { May }\end{array}$ & $\begin{array}{c}\text { Relative } \\
\text { humidity in } \\
\text { September }\end{array}$ \\
\hline $\begin{array}{c}\text { Moisture content } \\
\text { Dry matter } \\
\text { content }\end{array}$ & $0.927^{*}$ & $-0.929^{*}$ & -0.368 \\
Germination & -0.030 & -0.332 & $-0.865^{*}$ \\
\hline
\end{tabular}

$*=$ significant at $5 \%$. The correlation analysis was carried out with 61 variables, but only the variables that presented some significant correlation were shown.

changes, possibly biochemical changes in specific regions, such as the deposition of suberin and phenolic compounds in cells of the palisade layer, as mentioned by Smýkal et al. (2014). On the other hand, when seeds with different dormancy degrees are subjected to sulfuric acid, the responses differ considerably, probably due to the greater or lower penetration ease of the acid into the palisade layers containing such compounds, due to differences in their concentration in the testa cells. Thus, although the structure of dormant and non-dormant seeds is not different, structural differences may appear after the application of the acid, as verified in this work.

\section{Conclusions}

Different conditions during the formation of Erythrina speciosa seeds cause differences in both their dormancy degree and their susceptibility to breakage by acid scarification. Structural changes occurred equally in seeds with or without dormancy, so they are not individually responsible for the coat impermeability to water.

\section{Acknowledgments}

To the Biodiversity and Environment Post-Graduation Program (Institute of Botany) for the opportunity granted to the first author for his $\mathrm{PhD}$; to the Conselho Nacional de Desenvolvimento Cientifico e Tecnológico (CNPq) for the doctorate scholarships, awarded to D.M. Molizane and the productivity in research scholarship, awarded to S.M.CarmelloGuerreiro and C.J. Barbedo; to the Parque Cultural Catavento, for the collection permission. To the Scanning Electron Microscopy Laboratory of Institute of Botany.

\section{References}

BELITZ, H.D.; GROSCH, W.; SCHIEBERLE, P. Carbohydrates. In: BELITZ, H.D.; GROSCH, W.; SCHIEBERLE, P. Food Chemistry. Springer-Verlag Berlim Heidelberg, 2009. p.248-337.

BRASIL. Ministério da Agricultura, Pecuária e Abastecimento. Regras para análise de sementes. Brasília: MAPA/ACS, 2009. 395p. http://www.agricultura.gov.br/arq_editor/file/2946_regras_ analise_sementes.pdf

CHAI, M.; ZHOU, C.; MOLINA, I.; FU, C.; NAKASHIMA, J.; LI, G.; ZHANG, W.; PARK, J.; TANG, Y.; JIANG, Q.; WANG, Z.Y. A class II KNOX gene, KNOX 4, controls seed physical dormancy. Proceedings of the National Academy of Sciences, v.113, p.69977002, 2016. https://doi.org/10.1073/pnas.1601256113

CHAVES, I.S.; SILVA, N.C.Q.; RIBEIRO, D.M. Effect of seed coat on dormancy and germination in Stylosanthes humilis H.B.K. seeds. Journal of Seed Science, v.39, p.114-122, 2017. http://dx.doi. org/10.1590/2317-1545v39n2167773

COEN, O.; MAGNANI, E. Seed coat thickness in the evolution of angiosperms. Cellular and Molecular Life Sciences, v.75, on line first, 2018. https://doi.org/10.1007/s00018-018-2816-x

GAMA-ARACHCHIGE, N.S.; BASKIN, J.M.; GENEVE, R.L.; BASKIN, C.C. Acquisition of physical dormancy and ontogeny of the micropyle--water-gap complex in developing seeds of Geranium carolinianum (Geraniaceae). Annals of Botany, v.108, p.51-64, 2011. https://10.1093/aob/mcr103

HAY, F.R.; SMITH, R.D.; ELLIS, R.H.; BUTLER, L.H. Developmental changes in the germinability, desiccation tolerance, hardseededness, and longevity of individual seeds of Trifolium ambiguum. Annals of Botany, v.105, p.1035-1052, 2010. https:// www.ncbi.nlm.nih.gov/pubmed/20228084

HUANG, Z.; FOOTITT, S.; TANG, A.; FINCH-SAVAGE, W.E. Predicted global warming scenarios impact on the mother plant to alter seed dormancy and germination behaviour in Arabidopsis. Plant, Cell and Environment, v.41, p.187-197, 2017. https:// onlinelibrary.wiley.com/doi/epdf/10.1111/pce.13082

LEIVAS, J.; BERLATO, M.; FONTANA, D. Risco de deficiência hídrica decendial na metade sul do Estado do Rio Grande do Sul. Revista Brasileira de Engenharia Agrícola e Ambiental, v.10, p.297407, 2006. http://dx.doi.org/10.1590/S1415-43662006000200022

MANNING, J.C.; VAN STADEN, J. The development and ultrastructure of the testa and tracheid bar in Erythrina lysistemon Hutch. (Leguminosae: Papilionoideae). Protoplasma, v.129, p.157167, 1985. http://link.springer.com/article/10.1007/BF01279913

MARCOS-FILHO, J. Fisiologia de sementes de plantas cultivadas. Piracicaba: Fealq. 2015. 659p.

MELLO, J.I.O.; BARBEDO, C.J.; SALATINO, A.; FIGUEIREDORIBEIRO, R.C.L. Reserve carbohydrates and lipids from the seeds of four tropical tree species with different sensitivity to desiccation. Brazilian Archives of Biology and Technology, v.53, p.889-899, 2010. http://dx.doi.org/10.1590/S1516-89132010000400019 
MELLO, J.I.O.; CENTENO, D.C.; BARBEDO, C.J.; FIGUEIREDORIBEIRO, R.C.L. Changes in carbohydrate composition in seeds of three tropical tree species submitted to drying and storage at freezing temperature. Seed Science and Technology, v.39, p.465-480, 2011. https://doi.org/10.15258/sst.2011.39.2.18

O'BRIEN, T.P.; FEDER, N.; MCCULLY, M.E. Polychromatic staning of plant cell walls by toluidine blue. Protoplasma, v.59, p.368-373, 1964. http://link.springer.com/article/10.1007/BF01248568

PENFIELD, S.; MACGREGOR, D.R. Effects of environmental variation during seed production on seed dormancy and germination. Journal of Experimental Botany, v.68, p.819-825, 2017. https://doi. org/10.1093/jxb/erw436

PILATTI, F.K.; AGUIAR, T.; SIMÕES, T.; BENSON, E.E.; VIANA, A.M. In vitro and cryogenic preservation of plant biodiversity in Brazil. In Vitro Cellular \& Developmental Biology Plant, v.47, p.82-98, 2010. http://agris.fao.org/agris-search/search. do? recordID=US201301944942

ROLIM, G.D.E.S.; CAMARGO, M.B.P.; LANIA, D.G.; MORAES, J.F.L. Classificação climática de Köppen e de Thornthwaite e sua aplicabilidade na determinação de zonas agroclimáticas para o Estado de São Paulo. Bragantia, v.66, n.4, p.711-720, 2007. http:// www.scielo.br/pdf/brag/v66n4/22.pdf
SANTANA, D.G.; RANAL, M.A. Análise da germinação: um enfoque estatístico. Ed. UNB. 2004. 248p.

SMÝKAL, P.; VERNOUD, V.; BLAIR, M.W.; SOUKUP, A.; THOMPSON, R.D. The role of the testa during develoment and in establishment of dormancy of the legume seed. Frontiers in Plant Science, v.5, article 351, 2014. https://www.ncbi.nlm.nih.gov/pmc/ articles/PMC4102250/

SOUZA, T.V.; TORRES, I.C.; STEINER, N.; PAULILO, M.T.S. Seed dormancy in tree species of the Tropical Brazilian Atlantic Forest and its relationships with seed traits and environmental conditions. Brazilian Journal of Botany, v.38, p.243-264, 2015. https://link. springer.com/content/pdf/10.1007\%2Fs40415-014-0129-3.pdf

UENOJO, M.; PASTORE, G.M. Pectinases: Aplicações industriais e perspectivas. Quimica Nova, v.30, p.388-394, 2007. http://dx.doi. org/10.1590/S0100-40422007000200028. 